\title{
Sea-Level Rise in Northern Germany: A GIS-Based Simulation and Visualization
}

\author{
Caroline Schuldt ${ }^{1}$ (1) $\cdot$ Jochen Schiewe ${ }^{1}$. Johannes Kröger ${ }^{1}$
}

Received: 28 August 2020 / Accepted: 12 October 2020 / Published online: 2 November 2020

(c) The Author(s) 2020

\begin{abstract}
The future sea-level rise caused by climate change will lead to coastal regions being flooded and ecological and socioeconomic systems being disrupted. This study examines the question of how the sea-level rise in Northern Germany can be simulated on a regional level and visualized as a media map. The simulation is based on the TanDEM-X digital elevation model, IDW interpolated current measurements of the sea level and the vertical land movement, as well as regional sea surface elevation projections for the year 2100. Two different climate scenarios were applied based on IPCC forecasts. Particular attention was paid to transforming elevation systems into orthometric heights. In addition, the uncertainties existing in the simulation of future developments were quantified and visualized. Depending on the applied scenario, an area between 1061 and $9004 \mathrm{~km}^{2}$ will be inundated. Accordingly, the affected population varies between 5477 and 626,880 people. The calculation of the inundated areas reveals serious differences; between the various climate scenarios, as well as between the North and Baltic coasts, but above all between the assumption of a stable coastal protection on the one hand and a dike breach on the other. Based on the requirements of journalistic cartography and the specific requirements of the German broadcasting company Norddeutscher Rundfunk (NDR), static maps were developed, which will be shown as a sequence starting with the least and ending with the most severe possible impact.
\end{abstract}

Keywords Sea-level rise $\cdot$ GIS simulation $\cdot$ Regional $\cdot$ Visualization $\cdot$ Media maps

\section{Zusammenfassung}

In Folge des zukünftigen klimawandelbedingten Meeresspiegelanstiegs werden Küstenregionen überflutet und ökologische sowie sozioökonomische Systeme gestört. Die vorliegende Studie untersucht, wie der Meeresspiegelanstieg in Norddeutschland auf regionaler Ebene simuliert und als Medienkarte visualisiert werden kann. Die Simulation wird auf Basis des digitalen Höhenmodells TanDEM-X, mittels IDW interpolierten Messungen des aktuellen Meeresspiegels und der vertikalen Landbewegung sowie regionalen Prognosen zur Meeresoberflächenhöhe im Jahr 2100 erstellt. Auf Grundlage der IPCC-Prognosen wird auf zwei unterschiedliche Klimaszenarien eingegangen. Insbesondere wird darauf geachtet, dass Höhensysteme in orthometrische Höhen transformiert werden. Außerdem werden die bei der Simulation zukünftiger Entwicklungen bestehenden Unsicherheiten quantifiziert und visualisiert. Je nach angewendetem Szenario ist eine Fläche zwischen ca. 1061 und 10,116 km² betroffen. Dementsprechend schwankt die betroffene Bevölkerung zwischen 5477 und 753,656 Menschen. Bei der Berechnung der Überflutungsflächen zeigen sich gravierende Unterschiede—zum einen zwischen Nordund Ostseeküste, zum anderen zwischen den verschiedenen Klimaszenarien, besonders aber zwischen der Annahme eines standhaltenden Küstenschutzes und eines Deichbruchs. Ausgehend von den Anforderungen der journalistischen Kartographie sowie weiteren spezifischen Anforderungen des NDR werden statische Karten entwickelt, die als Sequenz beginnend mit den geringsten und abschließend mit den schlimmstmöglichen Auswirkungen gezeigt werden sollen.

\section{Introduction}

Caroline Schuldt

caroline.schuldt@hcu-hamburg.de

1 HafenCity Universität Hamburg, Hamburg, Germany
Sea-level rise is recognized as one of the greatest threats to coastal habitats worldwide (Nicholls et al. 2007). The resulting impacts are of both ecological and socio-economic 
importance and affect coastal landscapes, their ecosystem services, and coastal populations (Bryan et al. 2001). The increasing risks justify the interest in obtaining the most accurate insights into the extent of possible developments that will become apparent in the course of future sea-level rise. Taking different scenarios into account, an impression of the magnitude of possible changes can be given. However, as sea-level rise depends on many different influences, which are only predictable to a limited extent, the uncertainties of the simulation must also be calculated and presented. It is also questionable whether the existing dikes and barrages can stop flooding and what the situation would look like after a dike breach.

To make the abstract risks of climate change accessible, the scientific findings on sea-level rise must be visualized for the public. The media are socially of the greatest and most influential importance for the dissemination of cartographic information (Schiewe 2017). It needs to be clarified which distinctive features must be considered for the visualization with respect to journalistic use. To reach a broad public, the present research work was prepared in cooperation with the German broadcasting company Norddeutscher Rundfunk (NDR).

The focus is on the following research questions:

- How can sea-level rise in Northern Germany be simulated at regional level for the year 2100 ?

- How can the simulated sea-level rise be visualized as a media map?

Based on this, the following further questions are examined:

- Where are potentially inundated areas located considering different scenarios?

- What role does existing coastal protection play?

- What socio-economic consequences result from the predicted sea-level rise?

- To what extend is the simulation influenced by the uncertainties of the data used?

- What distinctive features must be taken into account in the visualization with regard to journalistic use?

\section{Literature Review}

Sea-level rise caused by climate change has been developing into a pressing problem for some years and is, therefore, a strongly studied phenomenon in science. Li et al. (2009) analyze the global sea-level rise by developing GIS-based methods to estimate the location, extent, and effects of potential flooding worldwide. For this purpose, an iterative process is used to search for DEM cells that are adjacent to the ocean and whose height is equal to or lower than the projected sealevel rise. The study also proposes interactive visualization techniques to show the progress and effects of potential flooding on maps. The target audience is the scientific community. It does not include the influence of the current sea level with local flood levels and the effects of coastal flood protection. Furthermore, the use of a uniform sea-level rise ignores the fact that changes in sea level do not occur uniformly throughout the world.

Lichter and Felsenstein (2012) present a method to simulate sea-level rise on a local level and to assess the resulting socioeconomic costs. For this purpose, low-lying raster cells of a DEM without connection to the coastline are counted as floodplains. Regional scenarios for sea-level rise are not considered, and uncertainties and local water levels are not included.

While the previously described publications develop methods for simulation, Bamber et al. (2019) integrate the modelling of uncertainties of sea-level rise. Structured expert judgements are used for this purpose. According to the expert group, the uncertainties have increased due to the growing knowledge about the involvement of inland ice.

Chu-Agor et al. (2011) also address uncertainties arising from the modelling of sea-level rise. Based on the sea level affecting marshes model, which is widely used to simulate wetland transformation and coastline changes, sensitivity and uncertainty analyses are performed.

The research by Strauss et al. (2015) on sea-level rise was conducted with the aim of visualizing the results for the general public. Maps are developed that can be individually adapted to the climate scenario and the location of the user on an interactive platform. The results were published in the Swiss newspaper "Blick" in 2019. For this purpose, static maps from different scenarios are superimposed and repeated, enabling the reader to compare the sea-level rise under different temperature rises. However, flooded areas in the interior of the country that have no connection to the sea are not considered. Uncertainties are also not visualized.

In summary, it is clear that despite the widely recognized relevance of the topic to the general public, sea-level rise has rarely been simulated and has not been visualized in a mediasuitable manner according to the necessary scientific standards and with the inclusion of uncertainties. Consequently, there is a need for further research in bringing together methodological considerations on simulation, journalistic visualization and the investigation and visualization of uncertainties.

\section{Data and Methodology}

\subsection{Study Area}

The study area is the entire German coast, that can be roughly divided into two parts, the Baltic Sea coast and the 
North Sea coast (Fig. 1). The federal states that border the German coast have an area of approx. $87,633 \mathrm{~km}^{2}$ with a population of 13,762,317 inhabitants (Statistische Ämter des Bundes und der Länder 2018: https://www.zensus2011 .de/DE/Home/Aktuelles/DemografischeGrunddaten.html). Characteristic for the Baltic Sea coast are the changing steep and flat coasts. In the case of steep coasts, the mainland is significantly higher than sea level. A large number of bays extend the coastline of the Baltic Sea enormously. As a result, the number of places that will be affected by rising sea levels is increasing.

The Wadden Sea along the North Sea coast is characterized by its location in the tidal influence zone. Because it is almost completely preserved in its natural state, it is Germany's most important natural area (Nationalpark Wattenmeer 2010: https://www.nationalpark-wattenmeer.de/). The Wadden Sea landscape is defined by the very slow decline of the seabed. Consequently, even a low tidal range floods large parts of the landscape. Another special feature of the German North Sea coast is the holms, whose coast does not possess sufficient dike protection.

\subsection{Parameters for the Simulation of Sea-Level Rise}

To model the complex system of a rising sea level as accurately as possible, a digital elevation model (DEM) and data on vertical land movement are considered to characterize the land surface. Sea level measurements and IPCC forecasts are used for simulating the water surface.

The DEM consists of data from the TanDEM-X mission, which are characterized by their homogeneous quality and previously unattainable accuracy (DLR 2018: https://www. dlr.de/content/en/missions/tandem-x.html). The elevation values represent the ellipsoidal heights of WGS84. The DEM has a $10 \mathrm{~m}$ absolute horizontal and vertical accuracy. With an inclination of less than $20 \%$, the relative vertical accuracy is $2 \mathrm{~m}$ (Wessel 2018). Since the relative vertical accuracy is $4 \mathrm{~m}$ at an inclination of more than $20 \%$, height errors in dikes and barrages have to be corrected in the DEM using aerial images. In addition, a second TanDEM-X based DEM is created, which is cleaned of all dikes. For this purpose, the dikes are identified using aerial images and their height is reduced in a raster calculation.

As the sea level locally deviates from $0 \mathrm{~m}$ above sea level (a.s.l.), the mean highest value of the water levels in a time span (MHW) is used. The use of the mean value ensures that no time-dependent values distort the current water level and thus the simulation of sea-level rise. For the Baltic Sea, measurements from 32 stations are available, where the MHW lies between 0.65 and $1.38 \mathrm{~m}$ a.s.l. In the North Sea, there are 133 stations where measurements are taken. Here, the MHW lies between 0.86 and $2.76 \mathrm{~m}$ a.s.l. (Wasserstraßen- und Schifffahrtsverwaltung 2019: https:// pegelonline.wsv.de/gast/hilfe).

The next essential factor for the simulation of sealevel rise is the prediction of height of the future sea surface. For this purpose, the IPCC forecasts from 2014 are adapted to the German coastal area. The Integrated Climate Data Center (ICDC) has analyzed how the geophysical sources that drive long-term changes in the sea surface height affect individual regions (Church et al. 2013). For the present study, five ice components (Greenland dynamic

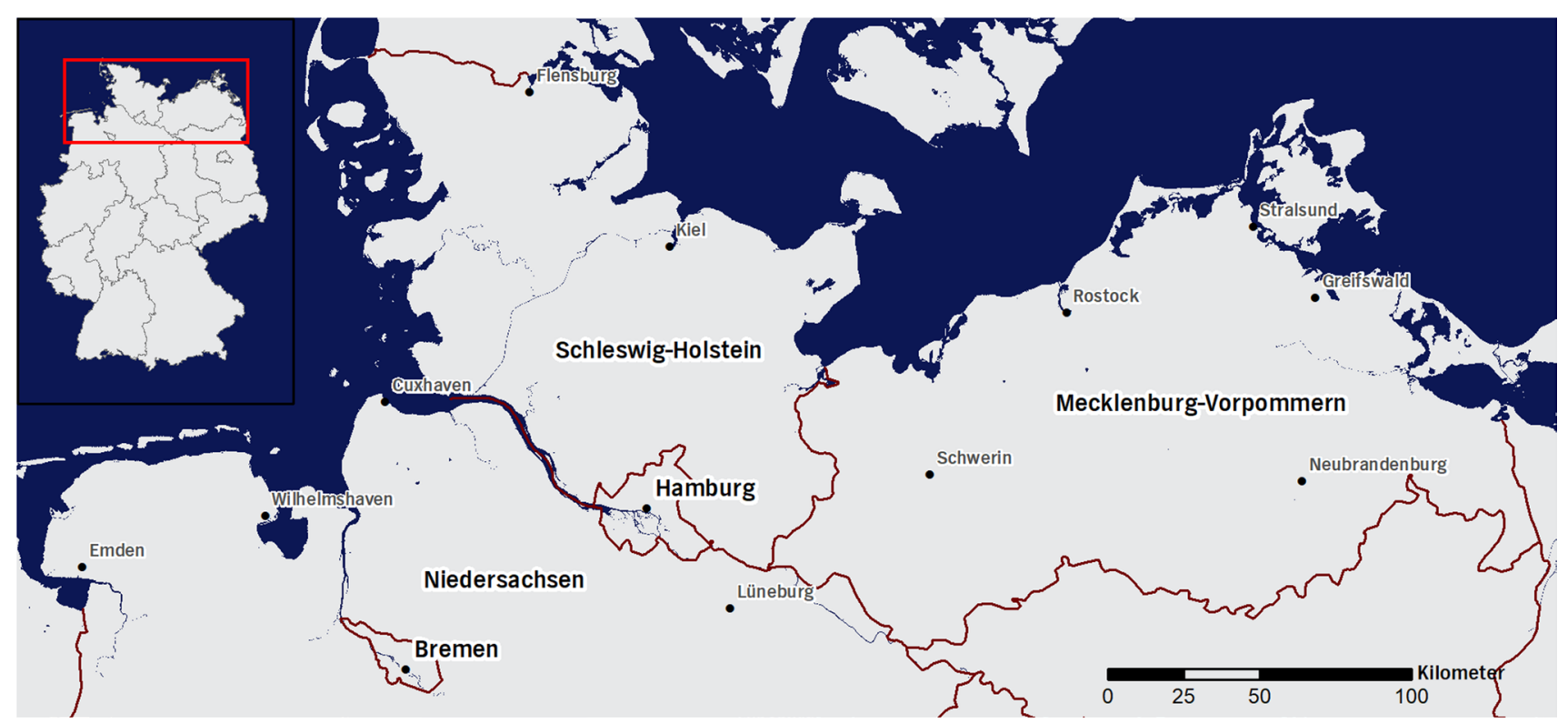

Fig. 1 Study area 
ice and surface mass balance, Antarctic dynamic ice and surface mass balance, and glaciers), three ocean-related components (dynamic sea surface height, global thermosteric anomaly, and the inverse barometer effect from the atmosphere), and land water storage are considered to determine the forecasts for the North Sea and Baltic Sea.

For the temperate scenario RCP4.5, in which the global mean surface temperature increases by $1.8^{\circ} \mathrm{C}$ until 2100 compared to the period 1986-2005, an increase in the relative sea surface of the North Sea of about $0.48 \mathrm{~m}$ is identified. For the Baltic Sea there is an average rise of $0.47 \mathrm{~m}$. In the scenario with very high greenhouse gas emissions $\mathrm{RCP} 8.5$, in which a temperature increase of $3.7^{\circ} \mathrm{C}$ is predicted, the mean value of the future sea surface rise of the North Sea is calculated at $0.71 \mathrm{~m}$. For the Baltic Sea the value is estimated at $0.73 \mathrm{~m}$ (ICDC 2019: https://icdc.cen. uni-hamburg.de/las/getUI.do).

Changes in relative sea-level rise not only include the rising sea surface but also changes in the height of the land area. On the one hand, this vertical land movement can mitigate climate change induced sea-level rise through coastal elevations. On the other hand, the sinking of landmasses exacerbates sea-level rise (Hanson et al. 2011). For this reason, sea-level rise deviates locally from sea-level rise forecasts (Church et al. 2013). For the present study data from the URL6a GPS solution are used, in which GPS data from 1995 to 2014 were analyzed. For the North Sea, there is an overall decrease of the earth's surface, while the Baltic Sea is generally rising (Santamaría-Gómez et al. 2017).

\subsection{Transforming Height Systems}

To combine the presented factors into a simulation of sealevel rise, the factors must have physically meaningful heights. The geoid, the equipotential surface of the earth's gravitational field, which approximately equals mean sea level in a least squares sense, is particularly suitable for elevations (NGS 2001: https://www.ngs.noaa.gov/GEOID /geoid_def.html). As Heiskanen and Moritz (1967, p. 172) write; 'Orthometric heights are the natural 'heights above sea level', that is, heights above geoid. They thus have an unequalled geometrical and physical significance.' For this reason, the heights of the DEM are converted to orthometric heights. Using the Geospatial Data Abstraction Library (GDAL), the DEM is transformed from the ellipsoidal heights in WGS84 to orthometric heights based on the model EGM96. EGM96 is an earth gravitational model published by the Office of Geomatics at National GeospatialIntelligence Agency. It is used as the geoid reference of the WGS84 ellipsoid. The orthometric heights are obtained by subtracting the geoid heights from the ellipsoidal heights.

\subsection{Identifying Floodplains}

Based on the factors presented, sea-level rise is simulated for the year 2100. The simulation is performed in ArcMap 10.6.1. The measurements of the MHW are interpolated to obtain an area-wide sea level from the point data. In addition, the point data for vertical land movement are interpolated. Both datasets have relatively homogeneous heights and depths (as numerically proven with a low variance). Comparison tests between inverse distance weighting (IDW) and Kriging did not show significant differences; therefore, IDW was chosen due to the shorter processing time.

In a raster calculation, the current sea level (SL), the predicted sea-level rise (SLR), the vertical land movement (VLM) and the DEM are then combined to obtain the area that is below future sea level-expressed by the inequality:

$\mathrm{DEM}+\mathrm{VLM} \leq \mathrm{SL}+\mathrm{SLR}$.

The front part of the equation represents the land side in 2100 , on the other side is the future sea side. The areas on land that are at an height less than or equal to the sea level are summarized as the area below sea level (Fig. 2).

In the following step, the area below sea level must be extracted from the calculated raster, which also contains the land area. For this purpose, the value of the raster cells above the future sea level is reclassified to NoData.

According to the developed raster, all areas below the predicted sea level are potentially flooded. This leads to lakes in the interior of the country, which do not exist in reality due to the missing connection to the sea. Areas below sea level that are protected by dikes are marked as flooded. However, the actual inundated area includes only those areas that border the coastline or flooded areas. For this reason, the raster containing the potential flood area is converted to a polygon feature and an iterative selection is performed. Not only the polygons that touch the coastline are selected, but also those that touch the polygons adjacent to the coastline and all other polygons that have indirect contact with the coastline. The iterative selection is programmed in Python 2.7 and integrated into ArcGIS via ArcPy. The result is the basic component of the sealevel rise simulation.

\subsection{Modeling Uncertainties}

However, the inundation area resulting from the simulation of sea-level rise cannot be presented with full clarity. Besides the future social, political, and economic decisions covered by the scenarios RCP4.5 and RCP8.5, there are limitations in the accuracy of the calculations 
Fig. 2 The terrain heights are added to the vertical land movement to obtain the height of the coast predicted in 2100 . The current sea level, added to the predicted rise, results in the sea level in 2100
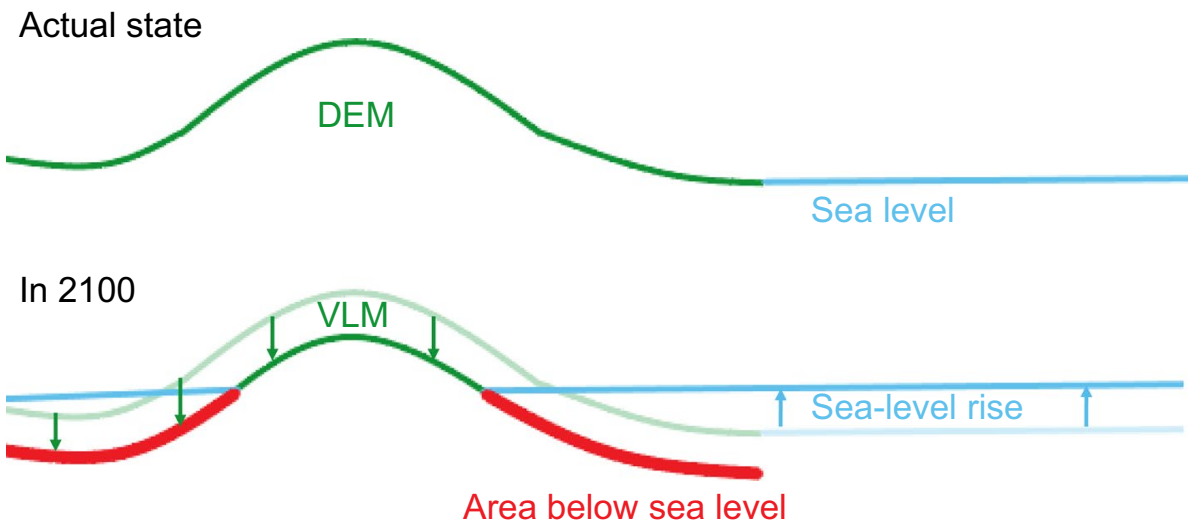

and measurements that influence the simulation. For this reason, the quantification of uncertainties is urgently required. Due to the complexity of the influences affecting ecosystems and biophysical processes, the predictions of future sea surface heights are given within a confidence interval. The height error map (HEM) as a component of the TanDEM-X DEM shows the uncertainties of the DEM. The values of the HEM represent for each raster cell the corresponding height error in terms of standard deviation. The value results from interferometric coherence and geometrical considerations. The height error is considered a random error (Wessel 2018). The uncertainties from the interpolation of the current sea level and VLM are quantified using the root mean square error (RMSE). When the uncertainties of the individual factors are combined, the calculation of the worst case scenario looks as follows:

$\mathrm{DEM}-\mathrm{HEM}+\mathrm{VLM}-\mathrm{RMSE}_{\mathrm{VLM}} \leq \mathrm{SL}+\mathrm{RMSE}_{\mathrm{SL}}+\mathrm{SLR}_{\mu}$.

The front part of the inequality represents the land side with the digital elevation model and the future change due to vertical land movement, while the back part represents the sea side with the sea level and its predicted rise. From the land side data, the uncertainties of the individual factors are subtracted, resulting in a land side decrease. On the sea side, the uncertainties are added and the highest value of sea-level rise within a probability of $90 \%$ is used, leading to an increase of the sea side. This causes a changed predicted coastline and a larger flooding area. In contrast to the worst case, the best case is calculated by increasing the land side and decreasing the sea side by uncertainties.

\subsection{Analysis of Socio-Economic Consequences}

To investigate the socio-economic consequences of sealevel rise, it is necessary to clarify which types of land cover, and how much of each type, might be flooded. It also examines how many of the current population would be directly affected. Therefore, the obtained inundation area is intersected with population distribution and land cover. The population distribution is derived from a census conducted in 2011, the results of which are available as raster cells with a resolution of $100 \mathrm{~m}$ (Statistische Ämter des Bundes und der Länder 2015). The CORINE Land Cover inventory provides uniform data on land cover and land use. For the data from 2012, a higher-resolution data set with 10 ha minimum mapping units was derived from the Land Cover Model 2012 (LBM-DE2012).

\subsection{Requirements of Journalistic Cartography}

The second focus of this work is the visualization of the results as media maps. Based on the distinctive features which characterize a media map according to Schiewe (2017), the following requirements can be developed for publishing the visualization on the website of the German broadcasting company NDR:

- The focus is on the design aesthetics and the presentation adapted in the context of the NDR website. Therefore, not all proven conventions of cartography can be considered. The corporate design of the NDR must be taken into account.

- Due to the heterogeneous group of NDR readers, the maps have to be prepared in a way that is easily readable for the public.

- The purpose of the maps on sea-level rise is both to convey and to illustrate information on possible future sea-level rise according to various scenarios. To convey the information within a short period, the main message must be in focus. The essentials should be recognizable at first glance and concisely illustrated.

\subsection{Implementation of the Visualization}

As a new example of journalistic cartography, a video sequence is planned for the visualization, in which the individual flooding scenarios are displayed one after the other 
for a short time. The order of the four maps results from the severity of the consequences: first the actual state, then scenario RCP4.5 and RCP8.5 each with existing coastal protection, then RCP8.5 without dike protection. This video sequence is repeated without the users having any influence on the playback speed.

To avoid overlapping of the heading with other text elements, the use of labels for e.g. city names is initially avoided. No geographical objects such as streets or borders are shown. The full focus should be directed towards the inundated area and thus enable the information to be conveyed in a short time.

In addition to the reduction of content, a simple intuitive coding of the flooded areas serves the understanding. The color table of the NDR is used here. Since water is associated with blue by default, blue tones are used for scenarios with coastal protection. To visualize that the water level is higher in scenario RCP8.5, a darker shade of blue is chosen than for scenario RCP4.5. The scenario without coastal protection stands for dike breaches where seawater penetrates strongly into the mainland. The danger to the population in such cases is indicated by a red signal color.

In addition to thematic information, a thematic map also includes information, which contains notes necessary for understanding the content. To do justice to the design aesthetics, not all information that belong in a map according to the conventions of cartography are included in the media maps. To focus on the inundated area and to avoid overlapping with other elements of the website, a legend is not included. The flooding areas can be recognized intuitively and are explained by text and symbols. The IPCC scenarios and their relation to global warming will be illustrated by a thermometer. Further information on the map such as the forecast year, map author, sources, and data are mentioned in the text. Only the map scale is essential for understanding.

\subsection{Visualizing Uncertainties}

To ensure the readability of the information on uncertainties in the simulated inundation and to support the users in the evaluation, a suitable visualization is of great importance (Kinkeldey and Schiewe 2012). The uncertainties as such need to be identified quickly and clearly. In the case of the large-scale maps shown in the video sequence, which cover the entire study area of Northern Germany, this is not possible due to the scale and the short observation period. However, precise information on the deviation from the forecast coastline and thus the areas whose inundation is uncertain becomes important when zooming in on small-scale areas. To visualize the uncertainties, the predicted coastline is shown as a dotted line, which makes the uncertainties of the information more intuitive. The uncertainty corridor, which runs on the upper and lower level of the coastline, is visualized as noise (see Fig. 6). This approach counteracts misinterpretations and allows a uniform color scheme (Schiewe 2016).

\section{Results}

The only content-related components of the maps are the mainland and the sea surface, which can be recognized by the observer at first glance due to their shape. For orientation, rivers are shown, while lakes and other water areas are filtered out of the DEM to support the clear appearance. Place names are omitted because the maps are overlaid by the headline of the article when published. In scenario RCP4.5, the inundated area is visualized in light blue (Fig. 3). It becomes clear that the dikes and barrages hold back the water and do not allow it to penetrate the mainland. In front of the dikes, however, the area is inundated. Besides the embankment foreland, this mainly affects the holms, which do not have sufficient coastal protection. According to RCP4.5, an area of about $476 \mathrm{~km}^{2}$ on the North Sea coast and $585 \mathrm{~km}^{2}$ on the Baltic Sea coast will be flooded (Table 1). Mecklenburg-Western Pomerania will lose the largest area with about $40 \%$ of the total inundation area. The affected area consists mainly of semi-natural areas, such as forests and wetlands, with about $560 \mathrm{~km}^{2}$ and agricultural areas with $388 \mathrm{~km}^{2}$. About $18 \mathrm{~km}^{2}$ of built-up areas and a total of 5477 people are directly affected by the rising sea level.

In the subsequent scenario RCP8.5, the sea-level rise is presented in addition to the sea-level rise based on RCP4.5 (Fig. 4). The higher sea-level rise is visualized with a darker blue. Due to the fact that the darker blue is hardly visible, it is clear that the inundated area increases only slightly. As in scenario RCP4.5, the flat land in front of the dikes is flooded, but the sea level does not exceed the dikes. According to RCP8.5, an area of approx. $513 \mathrm{~km}^{2}$ on the North Sea coast and $644 \mathrm{~km}^{2}$ on the Baltic Sea coast is flooded. 7636 people are affected.

With a higher water level, the dikes are more heavily loaded and the danger of a dike breach increases. For RCP8.5, a scenario is simulated and visualized in which the dikes cannot withstand the rising sea level. The associated danger is visualized with a signal color. This illustrates the difference to scenarios in which coastal protection prevents flooding to a considerable extent. In scenario RCP8.5, where the dikes cannot withstand the rising sea level, the large difference in the inundated area between the North and Baltic Sea is striking (Fig. 5). While only small flood areas appear on the high Baltic Sea coast, large areas along the low-lying North Sea coast are inundated. The inundation area at the North Sea rises to about $8096 \mathrm{~km}^{2}$. North Friesland with approx. $1268 \mathrm{~km}^{2}$, 
Fig. 3 Sea-level rise until 2100 according to RCP4.5 with existing coastal protection

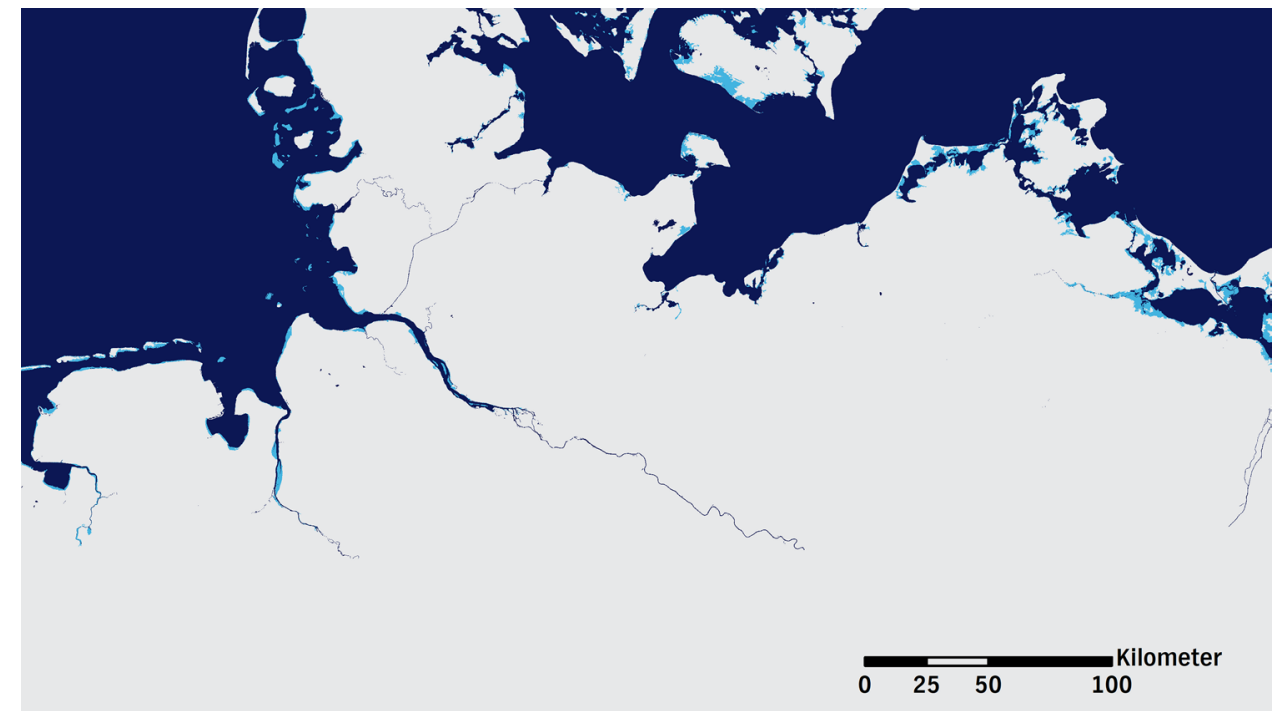

Table 1 Land area and people exposed to sea-level rise in different scenarios

\begin{tabular}{|c|c|c|c|c|}
\hline \multirow[t]{2}{*}{ Scenario } & \multicolumn{2}{|l|}{ North Sea } & \multicolumn{2}{|l|}{ Baltic Sea } \\
\hline & Area $\left(\mathrm{km}^{2}\right)$ & People & Area $\left(\mathrm{km}^{2}\right)$ & People \\
\hline $\mathrm{RCP} 4.5$ (average increase of $1.8^{\circ} \mathrm{C}$ ) with coastal protection & 476 & 1400 & 585 & 4077 \\
\hline RCP8.5 (average increase of $3.7^{\circ} \mathrm{C}$ ) with coastal protection & 513 & 1654 & 644 & 5982 \\
\hline RCP8.5 (average increase of $3.7^{\circ} \mathrm{C}$ ) without coastal protection & 8096 & 619,317 & 908 & 7563 \\
\hline
\end{tabular}

Fig. 4 Sea-level rise until 2100 according to RCP8.5 with existing coastal protection

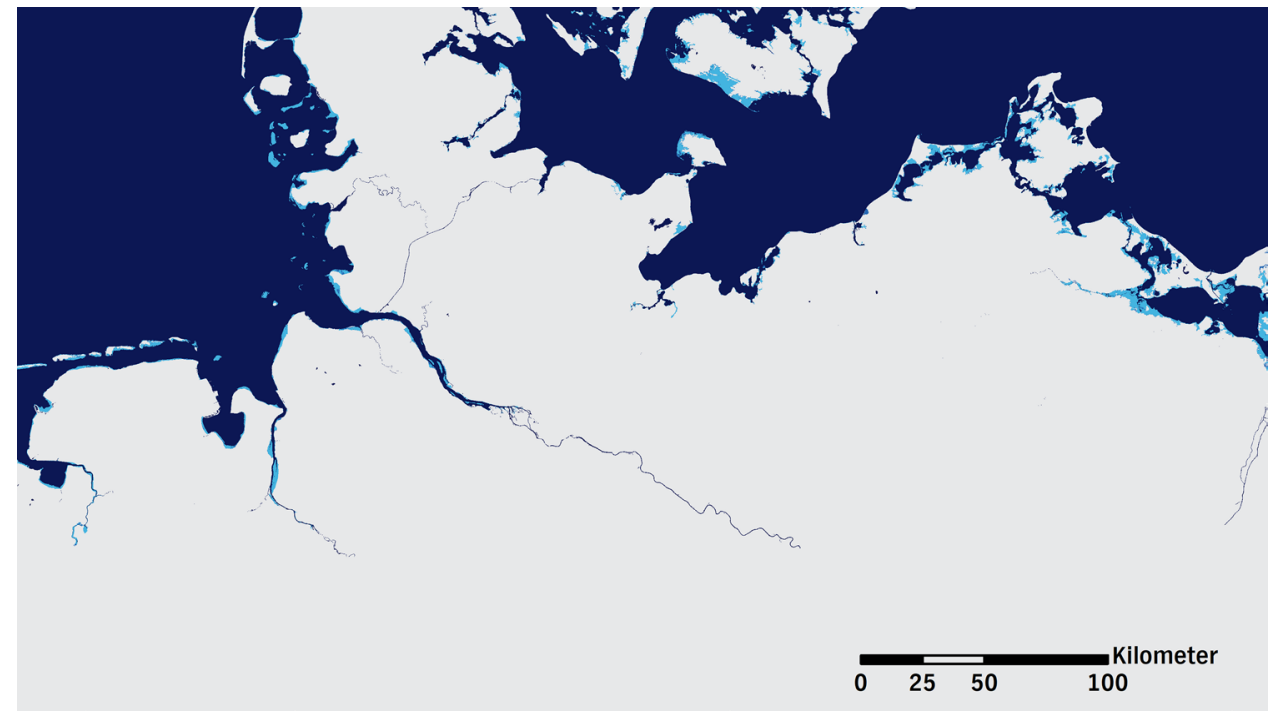

Dithmarschen with $991 \mathrm{~km}^{2}$ and Cuxhaven with $828 \mathrm{~km}^{2}$ lose the most land. The socio-economic consequences also change due to the intrusion of seawater into the mainland. In total, the living space of 626,880 people will be flooded. Also noteworthy is the increase in the affected agricultural areas from 432 to $7373 \mathrm{~km}^{2}$. Meadows and pastures are most affected, followed by arable land. In addition, $1135 \mathrm{~km}^{2}$ of semi-natural areas and $432 \mathrm{~km}^{2}$ of built-up areas are flooded. Among the built-up areas, the proportion of areas that are not entirely urban is the highest at approx. $293 \mathrm{~km}^{2}$.

In the event of a dike breach according to scenario RCP8.5, Wilhelmshaven will be completely behind the coastline forecast for 2100 (Fig. 6). In addition, compared to the inundated areas of the other districts of Northern 
Fig. 5 Sea-level rise until 2100 according to RCP8.5 without existing coastal protection

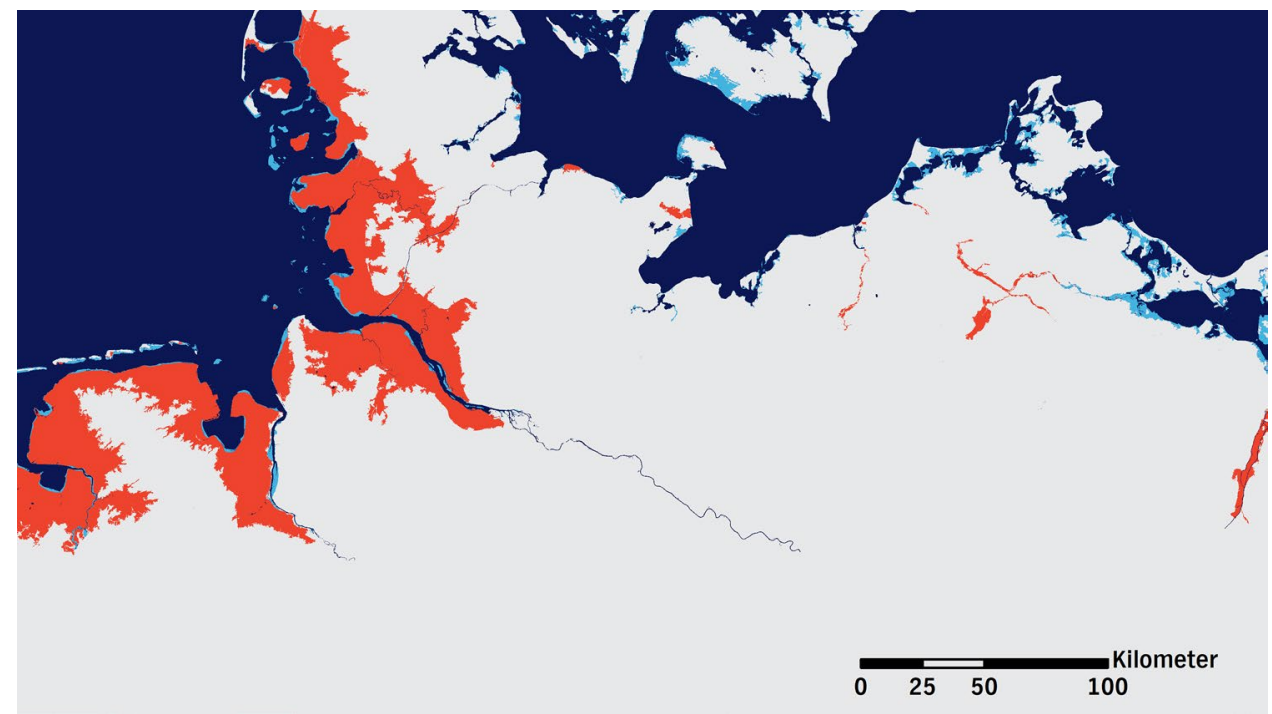

Germany, the city has the most densely populated area affected by sea-level rise, with approx. 693 people per $\mathrm{km}^{2}$.

For the local identification of affected area, the visualization of uncertainties plays a major role. Based on the uncertainty corridors it becomes clear that the coastline visualized as a dotted line can deviate from the predicted value. The simulation reacts particularly sensitively to the uncertainties of the DEM. With about $41 \%$ of the uncertain inundated area of all influencing factors, this factor has the greatest effect on the deviation from the predicted future coastline. The DEM is followed by the forecasts for sea-level rise.

\section{Limitations}

The methodological approach of the study has to be reflected on the limitations of the simulation of sea-level rise and its visualization as a media map. Interpolation methods applied to geophysical fields such as sea level distort essential aspects of physical properties. First, gradients are artificially introduced by the algorithm. On the other hand, discontinuities may not be preserved (Vieux 2016). Both lead to the fact that the interpolated surface deviates from the real sea level. However, the study shows that the simulation is
Fig. 6 Sea-level rise until 2100 according to RCP8.5 without existing coastal protection in Wilhelmshaven. The predicted coastline is visualized as a dotted line and the uncertainty corridor as noise

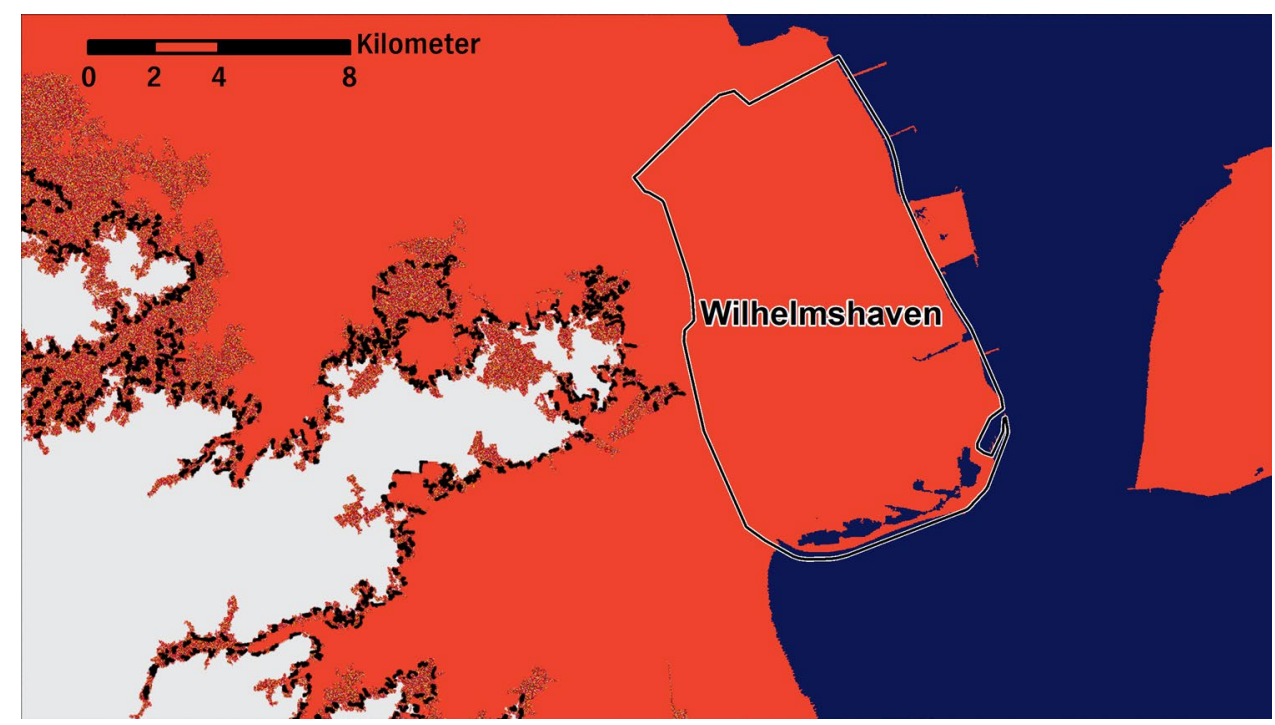


not sensitive to uncertainties caused by the interpolation of the current sea level and the vertical land movement. They still play a role when maps are zoomed in locally on certain areas. The visualization of uncertainties is therefore of great importance in this context.

In addition, there are restrictions with regard to visualization as media maps. Since the maps are to be published in a video sequence without interactivity, it is not possible for the users to zoom in on areas of interest on their own. Assuming that the existing dikes can withstand the increasing pressure of the sea, the flood areas in the individual scenarios are very similar. Even if this underlines the statement that even a small sea-level rise will flood the shallow dike foreland, it is difficult to identify the small differences.

\section{Conclusion}

The aim of the presented study on sea-level rise in Northern Germany was to create a GIS-based simulation and to visualize it as a media map. As a basis for the simulation, four factors that influence sea level regionally were identified. On the land side, the heights of the terrain are described using a TanDEM-X DEM transformed into orthometric heights and measurements of vertical land movement. The sea side results from the current water level interpolated with IDW and the regionally adjusted forecasts of the IPCC.

Especially the low embankment foreland and the holms on the North Sea coast are already strongly affected in RCP4.5, in which the global mean surface temperature increases by $1.8{ }^{\circ} \mathrm{C}$ until 2100 compared to the period 1986-2005. While the dikes and barrages prevent the water from penetrating into the mainland, extreme inundated areas on the North Sea coast appear if the dike breaks. The Baltic Sea coast is protected by the cliffs as a natural barrier against sea-level rise.

Static maps for the individual scenarios were designed. They will be shown in a video sequence; the presentation of the current status is followed by maps for the different scenarios, starting with the lowest and ending with the worst possible consequences. The focus was on a large-scale representation of the entire German coast as well as on the small-scale representation of areas that are of particular journalistic relevance. For these map sections, the different forecasts of sea-level rise were visualized with and without coastal protection.

Based on the requirements of journalistic cartography and the demands of the NDR, maps were created that should be easy to read due to their minimalist design. However, to make all information understandable, it is necessary to link the maps with a text. In this way, they can do justice to the heterogeneous target group of the digital mass medium. In addition, some labels, e.g. city names, will be included when the layout of the website is determined by the NDR.

A starting point for further research is the evaluation of the media maps produced. Here it must be examined whether the media maps are easily readable in view of the specific restrictions on display time, heterogeneous map literacy and the neglect of cartographic rules in favor of design aesthetics. An evaluation of usability is necessary to ensure that the users achieve the objectives effectively, efficiently, and satisfactorily.

Acknowledgements This article represents a shortened and revised version of a master's thesis (Schuldt 2019). The authors thank the German Aerospace Center (DLR) for offering the DEM data set used in this study.

Funding Open Access funding enabled and organized by Projekt DEAL.

Data Availability No.

Code Availability No.

\section{Compliance with Ethical Standards}

Conflict of Interest Not applicable.

Open Access This article is licensed under a Creative Commons Attribution 4.0 International License, which permits use, sharing, adaptation, distribution and reproduction in any medium or format, as long as you give appropriate credit to the original author(s) and the source, provide a link to the Creative Commons licence, and indicate if changes were made. The images or other third party material in this article are included in the article's Creative Commons licence, unless indicated otherwise in a credit line to the material. If material is not included in the article's Creative Commons licence and your intended use is not permitted by statutory regulation or exceeds the permitted use, you will need to obtain permission directly from the copyright holder. To view a copy of this licence, visit http://creativecommons.org/licenses/by/4.0/.

\section{References}

Bamber JL et al (2019) Ice sheet contributions to future sea-level rise from structured expert judgement. PNAS 116(23):11195-11200

Bryan B, Harvey N, Belperio T, Bourman B (2001) Distributed process modeling for regional assessment of coastal vulnerability to sea-level rise. Environ Model Assess 6(1):57-65

Chu-Agor ML et al (2011) Exploring vulnerability of coastal habitats to sea level rise through global sensitivity and uncertainty analyses. Environ Model Softw 26(5):593-604

Church JC et al (2013) Sea level change. In: Stocker TF et al (ed) Climate change 2013: the physical science basis. Contribution of working group I to the fifth assessment report of the intergovernmental panel on climate change, Cambridge University Press, Cambridge, New York, pp 1139-1216

Hanson S et al (2011) A global ranking of port cities with high exposure to climate extremes. Clim Change 104(1):89-111

Heiskanen WA, Moritz H (1967) Physical geodesy. Freeman, San Francisco 
Kinkeldey C, Schiewe J (2012) Visualisierung thematischer Unsicherheiten mit „Noise Annotion Lines”. Kartogr Nachr 62(5):241-249

Li X et al (2009) GIS analysis of global impacts from sea level rise. Photogramm Eng Remote Sens 75(7):807-818

Lichter M, Felsenstein D (2012) Assessing the costs of sea-level rise and extreme flooding at the local level: a GIS-based approach. Ocean Coast Manag 59:47-62

Nicholls RJ et al (2007) Coastal systems and low-lying areas. In: Parry $\mathrm{M}$ et al (ed) Climate change 2007: impacts, adaption and vulnerabilty. Contribution of working group II to the fourth assessment report of the intergovernmental panel on climate change, Cambridge University Press, Cambridge, New York, pp 315-356

Santamaría-Gómez A et al (2017) Uncertainty of the $20^{\text {th }}$ century sea-level rise due to vertical land motion errors. Earth Planet Sci Lett 473:24-32
Schiewe J (2016) Visualisierung unsicherer Informationen in Medienkarten-Notwendigkeit und kartographische Umsetzung. AGIT J 2:146-155

Schiewe J (2017) Journalistic cartography - setting the research agenda. Kartogr Nachr 67(5):245-253

Schuldt C (2019) Meeresspiegelanstieg in Norddeutschland. Eine GIS-basierte simulation und visualisierung (master's thesis). HCU Hamburg

Statistische Ämter des Bundes und der Länder (2015) Zensus 2011. Methoden und Verfahren. Wiesbaden

Strauss BH, Kulp S, Levermann A (2015) Mapping choices: carbon, climate, and rising seas, our global legacy. Climate Central, Princeton

Vieux BE (2016) Distributed hydrologic modeling using GIS. Springer, Dordrecht

Wessel B (2018) TanDEM-X ground segment - DEM products specification document. EOC, DLR, Oberpfaffenhausen 